\title{
Formal and Informal Volunteering and Health in Mediterranean Europe
}

\author{
By Damiano Fiorillo* \\ Nunzia Nappo ${ }^{*}$
}

In this paper, we compare the correlation among formal and informal volunteering and self-perceived health across Mediterranean European countries after controlling for socio-economic characteristics, housing features, neighborhood quality, size of municipality, social and cultural participation and regional dummies. We find that informal volunteering has a significant, positive correlation with self-perceived health in France, Spain, Greece and a significant, negative relationship in Italy.

Keywords: formal and informal volunteering, self-perceived health, Mediterranean European countries.

\section{Introduction}

Volunteering is an activity that people decide to practice spontaneously without any monetary return. One method to classify volunteering is by its formality (Wilson and Musick 1997). Formal volunteering is as any donation of time to activities of organizations. Informal volunteering (also called helping behaviour) is any support provided independently to non-households individuals, for instance advantaging an elderly (Carson 1999, Lee and Brudney 2012).

Largely social science has given more attention to formal volunteering than to informal volunteering. Although these activities share some obvious and non-obvious features, they are not equivalent. The former is more public than the latter, since formal volunteering is pushed by human capital, social capital and cultural capital more than informal volunteering (Wilson and Musick 199, Lee and Brudney 2012). Moreover, recent empirical studies on European Countries reach the conclusion that national dissimilarities in rates of formal and informal volunteering can be attributed to dissimilarities in human, social and cultural factors so as by contextual factors, among which countries' institutions (Plagnol and Huppert 2010).

This paper studies the relationship between formal and informal volunteering and health across some Mediterranean European countries. The contribution of this paper to the literature is double. First, it employs a new and comparable dataset, the 2006 wave EU-SILC micro data, a dataset rich of data on measures of volunteering for a sample of Mediterranean European Countries. Second, concentrating on self-perceived health in Mediterranean

\footnotetext{
*Assistant Professor, "Parthenope" University, Italy.

† Assistant Professor, University "Federico II" of Napoli, Italy.
} 
European Countries, the paper examines cross-countries dissimilarities between volunteering and self-perceived health in Europe, after controlling, among others, for human capital, social capital and cultural factors.

The paper is organized in the following way: section 2 studies channels through which volunteering may affect health. Sections 3 and 4 focus respectively on the dataset and the methodology. Section 5 illustrates the empirical analysis. Section 6 treats the results and section 7 presents conclusions.

\section{Volunteering and Health}

A large strand of the socio-medical literature has studied the relation between volunteering and health (Piliavin and Siegel 2007, Casiday et al. 2008, Tang 2009, Kumar et al. 2012). Potential channels through which volunteering benefits health may be related to the determinants of volunteering so as classified by the economic literature (Fiorillo and Nappo 2014b, 2015).

Volunteering may concur to make volunteers feel "good" (Andreoni 1990). According to this approach, volunteering can be considered as an ordinary consumption good (Menchik and Weisbrod 1987, Fiorillo 2011, Bruno and Fiorillo 2012, Nappo 2013) which provide a direct utility to individuals: volunteers draw utility also from volunteering in itself, not only from the goods they collaborate to supply. Therefore, volunteering gives people the chance to be recognized as "good" by society. Thus, volunteering affect positively volunteers' social recognition: volunteers are recompensed with gratitude and admiration and are considered altruist. So, being engaged in such activities may promote feelings of self-worth and self-esteem (Fiorillo and Nappo 2014b, 2015).

Another strand of the literature proposes that individuals volunteer to get work experience, which raises a volunteer's future employability, when he is unemployed, and earning power, when he is employed. In addition, some empirical studies argue that volunteers gain a wage premium (Day and Devlin 1998, Hackl et al. 2007, Bruno and Fiorillo 2015). Still, volunteering can improve workers' career prospects (Wilson 2000). This is likely to occur since volunteers are "team players" who are willing to collaborate with others (Kats and Rosemberg 2005), and therefore, more productive in the work place. Both the possibility of role enhancement and the wage premium linked to volunteering may increase job satisfaction (Fiorillo and Nappo 2014a) which, in turn, causes important positive effects on health (Faragher et al. 2005).

Making friends is a third determinant of volunteering: volunteering is an activity generally performed in groups, it is a way to expand one's personal network, and to ameliorate social skills too (Clotfelter 1985, Schiff 1990, Prouteau and Wolff 2006). There is a relation between this strand of the literature and the social integration theory, according to which multiple social roles provide meaning and purpose in life, encourage social support and relations ( $\mathrm{Li}$ and Ferraro 2005, Choi and Boham 2007). The integration theory 
states that people gain mental, emotional and physical advantages when they think themselves as a helping, accepted part of a community. Without such a feeling of joining, people can experience depression, loneliness and physical illness.

In our analysis, we would aspect a positive relationship among formal and informal volunteering and self-perceived health (Fiorillo and Nappo 2014b, 2015). In any case, since informal volunteering is not implemented through official groups but on individual basis, the others do not recognise informal volunteers' activities as they do for formal volunteering: consequently, the possible channel of "social recognition" might be weakened for informal volunteers. Usually, informal volunteers have fewer occasions to be valued by society than formal volunteers who, often, choose volunteering in well-known organizations, which offer them visibility with its benefits also in terms of health (Fiorillo and Nappo 2014b, 2015). Nevertheless, such reduced channels through which formal volunteering affect positively health might be balanced by the assumption that informal volunteering is likely performed for sole altruistic reasons, which, according to Freud - who supposed altruism as acting for one's own well-being - may influence positively health. Following a strand of the literature (see Batson 1991), altruistic people do not help in order to benefit others, but rather to receive advantages, to avoid distress and anxiety, and to release their sense of obligation.

\section{Data, Descriptive Statistics and Empirical Model}

The econometric analysis employs data from the Income and Living Conditions Survey carried out by the European Union's Statistics on Income and Living Conditions (EU-SILC) in 2006. The EU-SILC database makes available comparable multidimensional data on income, social exclusion and living conditions in European countries.

The dependent variable is self-perceived health, collected through personal interviews or registers, and assessed through the question: "In general, would you say that your health is very good, good, fair, poor, or very poor?". Responses are coded into a binary variable, which is equal to 1 in cases of good or very good health, 0 otherwise. Largely, the literature considers selfperceived health $(S P H)$ as a good proxy for health and, even though its very subjective nature, earlier studies have shown that it is correlated with objective measures of health as for instance mortality (Idler and Benyamini 1997).

We study formal and informal volunteering. The former (ForVol) is a dummy variable equal to 1 if the respondent, during the previous twelve months, worked unpaid for charitable organizations, groups or clubs (it includes unpaid work for churches, religious groups and humanitarian organizations and attending meetings connected with these activities), 0 otherwise. The latter (InfVol) is a binary variable equal to 1 if the respondent, during the previous twelve months, undertook (private) voluntary activities to help someone, such as cooking for others, taking care of people in hospitals/at 
home, taking people for a walk. Informal volunteering does not include any activity that the interviewed undertook for his/her household, in his/her work or within voluntary organizations.

In order to account for other factors that might influence both health status and formal and informal volunteering, we include in the analysis a full set of control variables (Fiorillo and Nappo 2014b, 2015). Table 5, in Appendix A, describes all variables considered in the empirical analysis.

Table 1. Descriptive Statistics (mean)

\begin{tabular}{|c|c|c|c|c|}
\hline & ES & FR & GR & IT \\
\hline SPH & 0.68 & 0.69 & 0.77 & 0.57 \\
\hline ForVol & 0.11 & 0.01 & 0.03 & 0.07 \\
\hline InfVol & 0.45 & 0.17 & 0.19 & 0.25 \\
\hline \multicolumn{5}{|l}{} \\
\hline Observations & 28055 & 19236 & 12606 & 45975 \\
\hline
\end{tabular}

Table 2. Correlation among SPH, ForVol and InfVol within European Countries

\begin{tabular}{|c|c|c|c|c|}
\hline & \multicolumn{2}{|c|}{ ES } & \multicolumn{2}{c|}{ FR } \\
\hline & SPH & ForVol & SPH & ForVol \\
\hline ForVol & -0.0048 & & 0.0043 & \\
\hline InfVol & $0.0437^{*}$ & $0.0897^{*}$ & $0.0290^{*}$ & $0.0755^{*}$ \\
\hline & \multicolumn{2}{|c|}{ GR } & \multicolumn{2}{c|}{ IT } \\
\hline & $S P H$ & ForVol & SPH & ForVol \\
\hline ForVol & $0.0323^{*}$ & & $0.0323^{*}$ & \\
\hline InfVol & $0.0414^{*}$ & $0.1848^{*}$ & $-0.0189^{*}$ & $0.1808^{*}$ \\
\hline
\end{tabular}

We consider 4 Mediterranean European Countries distinctly: Spain (ES), France (FR), Greece (GR), and Italy (IT).

Table 1 shows the weighted summary statistics for SPH, ForVol and InfVol. On average, respondents rate their health as good and/or very good, except for IT. Formal volunteering is the lowest in FR, where only $1 \%$ of respondents supply voluntary activities in charitable organizations, groups or clubs.

Table 2 shows the correlation matrix between the main variables of interest. We observe that the key independent variables are positively correlated each other for all countries, and positively correlated with the dependent variable in all countries, except for IT. This last descriptive evidence is not entirely true in the multivariate analysis.

Following Fiorillo and Nappo (2014b, 2015), self-perceived good health is represented through the following estimation equation:

$$
H_{i j}^{*}=\alpha+\beta F V_{i j}+\theta I V_{i j}+\chi Y_{i j}+Z_{i j} \varphi+\varepsilon_{i j}
$$

where, $H_{i j}^{*}$ is a "latent" variable, i.e. self-perceived health for individual $i$ in country $j ; F V_{i j}$ is formal volunteering provided by individual $i$ in country $j$; $I V_{i j}$ is informal volunteering performed by individual $i$ in country $j ; Y_{i j}$ is 
household income of individual $i$ in country $j ; Z_{i j}$ is a matrix of control variables that are known to influence self-perceived health and $\varepsilon$ is a randomerror term. $\alpha, \beta \theta, \chi, \varphi$ are parameters to be estimated.

We do not observe the "latent" variable $H_{i j}^{*}$ in the data. Rather, we observe $H_{i j}$ as a binary choice, which takes value 1 (very good or good perceived health) if $H_{i j}^{*}$ is positive and 0 otherwise. Consequently, the health equation (1) makes it appropriate for estimation as a Univariate Probit Model:

$$
\operatorname{Pr}\left(H_{i j}=1\right)=\Phi\left(\alpha-\beta F V_{i j}-\theta I V_{i j}-\chi Y_{i j}-Z_{i j} \varphi\right)
$$

where $\Phi(-)$ is the cumulative distribution function of a normal standard.

\section{Empirical Analysis}

Tables 3 and 4 show the univariate probit estimates for the 4 Mediterranean European Countries distinctly. Country by country, the first column reports marginal effects and the second column shows the standard errors, which are corrected for heteroskedasticity. Model (1) presents the findings with all the covariates except for social and cultural participation variables that are included in Model (2), where we conduct a robustness analysis.

In all Mediterranean countries informal volunteering matters. In Spain and France, the marginal effect of helping behaviour is statistically significant, respectively, at 1 and 5 percent, rising the probability of declaring selfperceived good health by 2.1 and 2.4 percent (Model 2). In Greece, the positive statistically significant association at 1 percent in Model (1) collapses to 10 percent in Model (2), even so indicating that informal voluntary activities increase the probability of reporting self-perceived good health of Greeks by 1.8 percent. However, in Italy, informal volunteering shows a negative statistically significant (at 1\%) correlation with health (Model 2). In IT, undertaking informal voluntary activities decreases the probability of reporting self-perceived good health by $2.3 \%$. In spite of helping behaviour, formal volunteering does not matter in all Mediterranean countries. Indeed, in Greece and Italy in Model (1), we observe a positive association between formal volunteering and health, statistically significant, respectively, at 10 and 1 percent. However, this association disappears in Model (2), when we control for social and cultural variables, meaning that social and cultural participation are relevant factors in driving the self-perceived health of Italians (Fiorillo 2013, Fiorillo and Sabatini 2011, Fiorillo and Sabatini 2015) and Greeks.

Results have to be treated with caution. Although we control for many covariates, the cross-section design of the data does not allow us to treat unobservable individual characteristics (as a panel data does). Moreover, a reverse causality has to be taken into consideration. 
Table 3. Probit Estimates Results: Mediterranean Countries \#1

\begin{tabular}{|c|c|c|c|c|c|c|c|c|}
\hline & \multicolumn{2}{|c|}{ ES(1) } & \multicolumn{2}{|r|}{ ES (2) } & \multicolumn{2}{|c|}{ FR (1) } & \multicolumn{2}{|c|}{ FR (2) } \\
\hline ForVol & -0.003 & 0.009 & -0.008 & 0.010 & 0.032 & 0.026 & 0.030 & 0.026 \\
\hline InfVol & $0.029 * * *$ & 0.006 & $0.021 * * *$ & 0.006 & $0.041 * * *$ & 0.008 & $0.024 * * *$ & 0.009 \\
\hline Female & $-0.029 * * *$ & 0.007 & $-0.022 * * *$ & 0.006 & -0.000 & 0.007 & -0.000 & 0.007 \\
\hline Married & -0.009 & 0.009 & -0.003 & 0.009 & -0.008 & 0.011 & -0.005 & 0.011 \\
\hline Separated/divorced & $-0.072 * * *$ & 0.015 & $-0.070 * * *$ & 0.015 & $-0.043 * *$ & 0.018 & $-0.045^{* * *}$ & 0.018 \\
\hline Widowed & $-0.047 *$ & 0.026 & $-0.047 *$ & 0.026 & $-0.042 * * *$ & 0.016 & $-0.040^{* *}$ & 0.016 \\
\hline Age 31- 50 & $-0.179 * * *$ & 0.013 & $-0.163 * * *$ & 0.013 & $-0.162 * * *$ & 0.015 & $-0.153 * * *$ & 0.016 \\
\hline Age 51- 64 & $-0.360 * * *$ & 0.015 & $-0.333 * * *$ & 0.016 & $-0.285 * * *$ & 0.019 & $-0.269 * * *$ & 0.020 \\
\hline Age $>65$ & $-0.457 * * *$ & 0.018 & $-0.425 * * *$ & 0.019 & $-0.450 * * *$ & 0.023 & $-0.431 * * *$ & 0.024 \\
\hline Lower secondary edu & $0.049 * * *$ & 0.008 & $0.043 * * *$ & 0.008 & $0.067 * * *$ & 0.011 & $0.057 * * *$ & 0.011 \\
\hline Secondary edu & $0.079 * * *$ & 0.008 & $0.070 * * *$ & 0.009 & $0.074 * * *$ & 0.009 & $0.065 * * *$ & 0.010 \\
\hline Tertiary edu & $0.118 * * *$ & 0.008 & $0.108 * * *$ & 0.009 & $0.125 * * *$ & 0.010 & $0.113 * * *$ & 0.010 \\
\hline Household size & $0.005 * *$ & 0.003 & $0.007 * * *$ & 0.003 & $0.006^{*}$ & 0.003 & $0.007 * *$ & 0.006 \\
\hline EU birth & 0.022 & 0.030 & 0.022 & 0.030 & $-0.033^{*}$ & 0.019 & -0.028 & 0.019 \\
\hline OTH birth & 0.004 & 0.016 & 0.012 & 0.016 & $-0.044 * * *$ & 0.014 & $-0.038 * * *$ & 0.014 \\
\hline $\begin{array}{c}\text { Household income } \\
\text { (ln) }\end{array}$ & $0.016^{* * *}$ & 0.004 & $0.014 * * *$ & 0.004 & $0.046^{* * *}$ & 0.007 & $0.042 * * *$ & 0.007 \\
\hline Uneed meet f.m.e. & $-0.113 * * *$ & 0.014 & $-0.107 * * *$ & 0.014 & $-0.146 * * *$ & 0.021 & $-0.131 * * *$ & 0.021 \\
\hline Homeowner & $0.012 * * *$ & 0.014 & 0.010 & 0.010 & $0.020 * *$ & 0.008 & $0.016^{*}$ & 0.009 \\
\hline Employed part time & $-0.039 * * *$ & 0.015 & $-0.041 * * *$ & 0.015 & $-0.065 * * *$ & 0.014 & $-0.066 * * *$ & 0.014 \\
\hline Unemployed & $-0.067 * * *$ & 0.014 & $-0.065 * * *$ & 0.014 & $-0.110 * * *$ & 0.017 & $-0.110^{* * *}$ & 0.017 \\
\hline Student & $0.076^{* * * *}$ & 0.017 & $0.067 * * *$ & 0.017 & 0.018 & 0.021 & 0.006 & 0.021 \\
\hline Retired & $-0.158 * * *$ & 0.014 & $-0.156^{* * * *}$ & 0.014 & $-0.128 * * *$ & 0.015 & $-0.130 * * *$ & 0.015 \\
\hline Disabled & $-0.612 * * *$ & 0.018 & $-0.606^{* * *}$ & 0.019 & $-0.349 * * *$ & 0.021 & $-0.334 * * *$ & 0.022 \\
\hline Domestic tasks & $-0.093 * * *$ & 0.012 & $-0.093 * * *$ & 0.012 & $-0.080 * * *$ & 0.019 & $-0.078 * * *$ & 0.019 \\
\hline Inactive & $-0.159 * * *$ & 0.017 & $-0.160 * * *$ & 0.017 & $-0.277 * * *$ & 0.035 & $-0.264 * * *$ & 0.037 \\
\hline Home warm & $0.116^{* * * *}$ & 0.012 & $0.107 * * *$ & 0.012 & $0.110^{* * * *}$ & 0.016 & $0.098 * * *$ & 0.016 \\
\hline Home dark problem & $-0.081 * * *$ & 0.008 & $-0.079 * * *$ & 0.009 & $-0.064 * * *$ & 0.012 & $-0.060 * * *$ & 0.012 \\
\hline Noise & $-0.044 * * *$ & 0.008 & $-0.044 * * *$ & 0.008 & $-0.036^{* * * *}$ & 0.010 & $-0.040 * * *$ & 0.010 \\
\hline Pollution & $-0.043 * * *$ & 0.009 & $-0.042 * * *$ & 0.009 & $-0.050 * * *$ & 0.011 & $-0.051 * * *$ & 0.011 \\
\hline Crime & $-0.051 * * *$ & 0.009 & $-0.050 * * *$ & 0.009 & $-0.039 * * *$ & 0.010 & $-0.042 * * *$ & 0.010 \\
\hline $\begin{array}{l}\text { Densely populated } \\
\text { area } \\
\end{array}$ & 0.012 & 0.008 & 0.013 & 0.008 & $0.019^{*}$ & 0.011 & $0.022^{* *}$ & 0.011 \\
\hline Intermediate area & 0.010 & 0.009 & 0.008 & 0.009 & 0.012 & 0.010 & 0.013 & 0.010 \\
\hline Political parties/t.u. & & & $-0.027 *$ & 0.016 & & & -0.023 & 0.021 \\
\hline Professional part. & & & 0.002 & 0.015 & & & -0.032 & 0.035 \\
\hline Religious part. & & & -0.007 & 0.008 & & & 0.015 & 0.026 \\
\hline Recreational part. & & & $0.031 * * *$ & 0.009 & & & $0.043 * * *$ & 0.008 \\
\hline Other org. part. & & & -0.020 & 0.012 & & & $-0.019^{*}$ & 0.011 \\
\hline Meetings with friends & & & $0.051^{* * *}$ & 0.007 & & & $0.030 * * *$ & 0.007 \\
\hline Cinema & & & $0.036 * * *$ & 0.008 & & & 0.007 & 0.008 \\
\hline Live performance & & & $0.015^{*}$ & 0.008 & & & $0.039 * * *$ & 0.007 \\
\hline Cultural site & & & $0.017 * *$ & 0.007 & & & $0.015^{*}$ & 0.008 \\
\hline Sport events & & & $0.037 * * *$ & 0.010 & & & 0.022 & 0.010 \\
\hline Regional dummies & \multicolumn{2}{|l|}{ Yes } & \multicolumn{2}{|l|}{ Yes } & \multicolumn{2}{|l|}{ Yes } & \multicolumn{2}{|l|}{ Yes } \\
\hline Pseudo R2 & \multirow{3}{*}{\multicolumn{2}{|c|}{$\begin{array}{c}0.232 \\
26157 \\
-12495.85\end{array}$}} & \multirow{3}{*}{\multicolumn{2}{|c|}{$\begin{array}{c}0.234 \\
25755 \\
-12216.04 \\
\end{array}$}} & \multirow{3}{*}{\multicolumn{2}{|c|}{$\begin{array}{c}0.215 \\
18929 \\
-8982.22\end{array}$}} & \multirow{3}{*}{\multicolumn{2}{|c|}{$\begin{array}{c}0.215 \\
18231 \\
-8547.24 \\
\end{array}$}} \\
\hline Observations & & & & & & & & \\
\hline Log likelihood & & & & & & & & \\
\hline
\end{tabular}

Note: The symbols $* * *, * *, *$ denote that the marginal effect is statistically different from zero at 1,5 and 10 percent. 
Table 4. Probit Estimates Results: Mediterranean Countries \#2

\begin{tabular}{|c|c|c|c|c|c|c|c|c|}
\hline & \multicolumn{2}{|c|}{ GR (1) } & \multicolumn{2}{|c|}{ GR(2) } & \multicolumn{2}{|c|}{ IT (1) } & \multicolumn{2}{|l|}{ IT (2) } \\
\hline ForVol & $0.037 *$ & 0.019 & 0.020 & 0.020 & $0.032 * * *$ & 0.010 & 0.005 & 0.011 \\
\hline InfVol & $0.025 * * *$ & 0.009 & $0.018^{*}$ & 0.009 & -0.010 & 0.006 & $0.023 * * *$ & 0.006 \\
\hline Female & -0.007 & 0.009 & -0.003 & 0.009 & - $0.026 * * *$ & 0.006 & $0.021 * * *$ & 0.006 \\
\hline Married & 0.008 & 0.015 & 0.008 & 0.015 & - $0.041 * * *$ & 0.008 & $\overline{-}-038 * * *$ & 0.008 \\
\hline Separated/divorced & $-0.051 * * *$ & 0.021 & $-0.049 * *$ & 0.021 & $0.108 * * *$ & 0.012 & $0.104 * * *$ & 0.012 \\
\hline Widowed & $-0.123 * * *$ & 0.040 & $-120 * * *$ & 0.040 & $-0.051 * *$ & 0.021 & $0.057 * * *$ & 0.021 \\
\hline Age 31- 50 & $-0.117 * * *$ & 0.023 & $\overline{0.105^{* * *}}$ & 0.022 & $\overline{0.206 * * *}$ & 0.011 & $-\overline{0.185 * * *}$ & 0.011 \\
\hline Age 51- 64 & $-0.306^{* * *}$ & 0.031 & $-\overline{0.282 * * *}$ & 0.031 & $\begin{array}{l}- \\
0.390 * * *\end{array}$ & 0.011 & $\begin{array}{l}- \\
0.369 * * *\end{array}$ & 0.012 \\
\hline Age $>65$ & $-0.475^{* * *}$ & 0.032 & 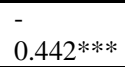 & 0.033 & $\overline{-}-542 * * *$ & 0.011 & $\overline{0}-523 * * *$ & 0.011 \\
\hline Lower secondary edu & $0.064 * * *$ & 0.010 & 0.060 *** & 0.010 & $0.097 * * *$ & 0.008 & $0.083^{* * *}$ & 0.008 \\
\hline Secondary edu & $0.084 * * *$ & 0.009 & $0.076^{* * * *}$ & 0.009 & $0.154 * * *$ & 0.008 & $0.135 * * *$ & 0.008 \\
\hline Tertiary edu & $0.096 * * *$ & 0.010 & $0.085 * * *$ & 0.010 & $0.199 * * *$ & 0.009 & $0.176 * * *$ & 0.010 \\
\hline Household size & $0.006^{*}$ & 0.003 & $0.008^{* *}$ & 0.003 & $0.019 * * *$ & 0.003 & $0.021 * * *$ & 0.003 \\
\hline EU birth & 0.015 & 0.038 & 0.032 & 0.034 & $0.100 * * *$ & 0.022 & $0.108 * * *$ & 0.022 \\
\hline OTH birth & $-0.047 * *$ & 0.020 & -0.029 & 0.019 & $0.098 * * *$ & 0.014 & $0.107 * * *$ & 0.014 \\
\hline $\begin{array}{l}\text { Household income } \\
\text { (ln) }\end{array}$ & $0.029 * * *$ & 0.006 & $0.024 * * *$ & 0.006 & $0.018 * * *$ & 0.005 & $0.017 * * *$ & 0.005 \\
\hline Uneed meet f.m.e. & $-0.222 * * *$ & 0.021 & $0.211 * * *$ & 0.021 & $0.229 * * *$ & 0.011 & $0.224 * * *$ & 0.011 \\
\hline Homeowner & -0.011 & 0.010 & -0.014 & 0.010 & -0.005 & 0.006 & -0.010 & 0.007 \\
\hline Employed part time & -0.027 & 0.020 & -0.027 & 0.020 & $0.032 * * *$ & 0.012 & $-0.030 * *$ & 0.012 \\
\hline Unemployed & $-0.067 * * *$ & 0.024 & - $0.066^{* * * *}$ & 0.024 & $-\overline{0.056 * * *}$ & 0.013 & $-0.028 * *$ & 0.013 \\
\hline Student & 0.036 & 0.028 & 0.025 & 0.028 & $0.061 * * *$ & 0.016 & $0.058 * * *$ & 0.016 \\
\hline Retired & $-0.174 * * *$ & 0.016 & $0.166^{* * *}$ & 0.016 & $0.097 * * *$ & 0.010 & $0.084 * * *$ & 0.010 \\
\hline Disabled & $-0.768 * * *$ & 0.031 & $0.752 * * *$ & 0.036 & $0.465 * * *$ & 0.017 & $0.467 * * *$ & 0.019 \\
\hline Domestic tasks & $-0.111^{* * *}$ & 0.016 & $0.105^{* * *}$ & 0.016 & $0.044 * * *$ & 0.009 & $0.028 * * *$ & 0.010 \\
\hline Inactive & $-0.187 * * *$ & 0.047 & $-175^{* * *}$ & 0.047 & $0.134 * * *$ & 0.014 & $0.109 * * *$ & 0.014 \\
\hline Home warm & $0.042 * * *$ & 0.012 & $0.041 * * *$ & 0.012 & $0.048 * * *$ & 0.010 & $0.037 * * *$ & 0.010 \\
\hline Home dark problem & $-0.057 * * *$ & 0.010 & $0.051 * * *$ & 0.010 & $\begin{array}{l}- \\
0.111 * * * \\
\end{array}$ & 0.007 & $-\overline{0.107 * * *}$ & 0.007 \\
\hline Noise & $-0.045^{* * *}$ & 0.012 & - $0.045 * * *$ & 0.011 & $-\overline{0.035 * * *}$ & 0.007 & $0.036 * * *$ & 0.007 \\
\hline Pollution & $-0.031 * *$ & 0.014 & $-0.023^{*}$ & 0.013 & $\begin{array}{l}- \\
0.025 * * * \\
\end{array}$ & 0.008 & $0.026 * * *$ & 0.008 \\
\hline Crime & -0.017 & 0.016 & -0.009 & 0.016 & $\begin{array}{l}- \\
0.024 * * *\end{array}$ & 0.009 & $-0.019 * *$ & 0.009 \\
\hline $\begin{array}{l}\text { Densely populated } \\
\text { area }\end{array}$ & -0.006 & 0.010 & -0.005 & 0.010 & $0.034 * * *$ & 0.007 & $0.037 * * *$ & 0.007 \\
\hline Intermediate area & 0.002 & 0.014 & 0.002 & 0.013 & $0.025 * * *$ & 0.007 & $0.022 * * *$ & 0.007 \\
\hline Political parties/t.u. & & & 0.012 & 0.020 & & & $0.042 * * *$ & 0.014 \\
\hline Professional part. & & & 0.009 & 0.020 & & & $0.043 * * *$ & 0.013 \\
\hline Religious part. & & & $0.018^{* *}$ & 0.008 & & & 0.000 & 0.007 \\
\hline Recreational part. & & & 0.010 & 0.016 & & & $0.029 * * *$ & 0.009 \\
\hline Other org. part. & & & -0.000 & 0.020 & & & 0.014 & 0.013 \\
\hline Meetings with friends & & & $0.048 * * *$ & 0.010 & & & $0.078 * * *$ & 0.006 \\
\hline Cinema & & & 0.012 & 0.012 & & & $0.049 * * *$ & 0.007 \\
\hline
\end{tabular}




\begin{tabular}{|c|c|c|c|c|c|c|}
\hline Live performance & & $0.027 * *$ & 0.011 & & $0.035 * * *$ & 0.007 \\
\hline Cultural site & & $0.037 * *$ & 0.013 & & $0.017^{* * *}$ & 0.008 \\
\hline Sport events & & 0.023 & 0.014 & & $0.023 * * *$ & 0.009 \\
\hline Regional dummies & Yes & \multicolumn{2}{|l|}{ Yes } & Yes & \multicolumn{2}{|l|}{ Yes } \\
\hline Pseudo R2 & 0.378 & \multicolumn{2}{|c|}{0.381} & 0.264 & \multicolumn{2}{|c|}{0.270} \\
\hline Observations & 12088 & \multirow{2}{*}{\multicolumn{2}{|c|}{12008}} & \multirow{2}{*}{45497} & \multicolumn{2}{|c|}{43808} \\
\hline Log likelihood & -4192.49 & & & & \multicolumn{2}{|c|}{-21748.39} \\
\hline
\end{tabular}

Despite these limitations, our findings provide the debate on the relationship between volunteering and health with significant insights, encouraging us to develop this course of research.

\section{Summary and Discussion}

Volunteering is confirmed to be correlated with health. Our findings are in line with previous research: in particular, with Borgonovi (2008), who employing the US data, finds a positive correlation between volunteer labour and self-reported health, and with Petrou and Kupek (2008) who, using data on England, show a positive correlation between an individual's activities in a wide range of social organisations and self-reported good health. In addition, as concerns the EU countries, results are in accordance with Fiorillo and Nappo (2014b, 2015), who show the beneficial role of both volunteering and community cohesion on health. However, we also remark negative correlations between health and informal volunteering for IT. Hence, relevant crosscountries differences do exist.

In Greece and Italy, results show a statistically positive association between formal voluntary work and health in Model (1). Such results might be explained considering that both Greece and Italy are characterised by a weak welfare regime, so volunteers could perceive their activities as supportive. In addition, in those countries policy makers are orientated to make volunteering a way to empower citizens who should not expect everything done for them by others or by the government. Again, it could be said that where volunteering is perceived as more necessary in terms of social benefits, its impact on health is greater.

As regards informal volunteering, we found a significant, positive correlation with self-rated health in France and in Spain. People informally volunteer especially induced by altruistic motivations, and it may happen that altruistic volunteers gain great benefit from volunteering, which, in turn, have a positive impact on health. Altruists, helping other, feel good, since lessen, or avoid distress and anxiety. However, results are different for Italy, where performing informal volunteering lessens the probability of reporting selfperceived good health. Within the Italian economic scenario, volunteering plays a crucial role in the welfare sector. Results show that Italians are altruistic and care about others without caring about their own health, probably 
because they are particularly aware of others' needs of help in a context where public provision of services is quite low.

It is important to note how, as regards formal volunteering, results differ between Model (1) and Model (2): while the former does not include social and cultural participation covariates, the latter does. As said, one of the reasons why people volunteer is making friends and meeting other people. Social relationships affect health. Larger overall involvement with formal (for instance recreational organizations and volunteering groups) and informal (for instance friends and neighbours) social ties affect positively health by several channels: 1) positive health behaviours (Berkman and Breslow 1983), 2) psychosocial mechanisms (for example social support and mental health) and 3) physiological processes (for example, helpful interactions with others benefit immune, endocrine, and cardiovascular systems - Uchino 2004). Results confirm the above statement for volunteering in Models (1) and for some social and cultural participation covariates in Models (2). When the model includes social and cultural participation covariates, some of them are important predictors of self-perceived health, while the effect of volunteering on health lessens or disappears (Greece and Italy). This means that social and cultural participation variables in Models (2) capture the beneficial effect of social relationships on health due to formal volunteering in Models (1). Namely, individuals with poor social life expand their personal network volunteering in formal organizations and through these social relations gain health benefits. While, individuals with a rich social life, including participation in formal volunteering organizations, obtain health benefits from other kinds of social relationships.

\section{Conclusions}

In this paper, we compare the correlation among formal and informal volunteering and self-perceived health across some Mediterranean European Countries after controlling for socio-economic characteristics, housing features, neighborhood quality, size of municipality, social and cultural participation and regional dummies. We perform univariate probit models (Fiorillo Nappo 2014b, 2015). Our results expand the existing literature on formal and informal volunteering and health showing that they have a distinct correlation with health perception and that such effects differ across countries. A limit of the paper is that it studies only correlation, without considering causation. Research that can solve the reverse causality problem should be the next step of the study: however, such a problem cannot be solved with data available.

\section{References}

Andreoni J (1990) Impure altruism and donations to public goods: a theory of warm glow giving. Economic Journal 100(401): 45-52. 
Berkman L, Breslow L (1983) Health and Ways of Living. New York, NY: Oxford University Press.

Borgonovi F (2008) Doing well by doing good: the relationship between formal volunteering and self-reported health and happiness. Social Science \& Medicine 66(11): 2321-2334.

Bruno B, Fiorillo D (2015) Voluntary work and wages. Annals of Public and Cooperative Economics [forthcoming].

Bruno B, Fiorillo D (2012) Why without pay? Intrinsic motivation in the unpaid labour supply. Journal of Socio-Economics 41: 659-669.

Carson ED (1999) On defining and measuring volunteering in the United States and abroad. Law and Contemporary Problems 62(4): 67-72.

Casiday R, Kinsman E, Fisher C, Bambra C (2008) Volunteering and health; what impact does it really have? Final Report to Volunteering England - Department of Voluntary Sector Studies, University of Wales Lampeter.

Choi NG, Bohman TM (2007) Predicting the changes in depressive symptomatology in later life: How much do changes in health status, marital and caregiving status, work and volunteering, and health-related behaviours contribute. Journal of Aging and Health 19(1): 152 - 177.

Clotfelter CT (1985) Federal Tax Policy and Charitable Giving. Chicago: University of Chicago Press.

Day KM, Devlin RA (1998) The Payoff to Work without Pay: Volunteer Work as an Investment in Human Capital. Canadian Journal of Economics 31(5): 1179-1191.

Faragher BE, Cass M, Cooper CL (2005) The relationship between job satisfaction and health: A meta-analysis. Occupational and Environmental Medicine 62(2): 105-112.

Fiorillo D (2013) Workers' health and social relations in Italy. Health, Econometrics and Data Group Working Paper 13/32.

Fiorillo D (2011) Do monetary rewards crowd out intrinsic motivation to volunteers? Some empirical evidence for Italian volunteers. Annals of Public and Cooperative Economics 82 (2): 139-165.

Fiorillo D, Nappo N (2014a) Job satisfaction in Italy: individual characteristics and social relations, International Journal of Social Economics 41(8): 1019-1041.

Fiorillo D, Nappo N (2014b) Formal and informal volunteering and health across European countries, MPRA Paper 54130. Germany: University Library of Munich.

Fiorillo D, Nappo N (2015) Formal volunteering and self-perceived health. Causal evidence from the UK-SILC. Health, Econometrics and Data Group (HEDG) Working Papers 15/06, c/o. Department of Economics, University of York;

Fiorillo D, Sabatini S (2015) Structural social capital and health in Italy. Economics and Human Biology 17: 129-145.

Fiorillo D, Sabatini S (2011) Quality and quantity: the role of social interactions in self-reported individual health. Social Science \& Medicine 73(11): 1644-1652.

Hackl F, Halla M, Pruckner GJ (2007) Volunteering and Income - The fallacy of the good samaritan?. Kyklos 60(1): 77-104.

Idler EL, Benyamini Y (1997) Self-rated health and mortality: a review of twentyseven community studies. Journal of Health and Social Behavior 38(1): 21-37.

Kats E, Rosemberg J (2005) An Economic Interpretation of Institutional Volunteering. European Journal of Political Economy 21(2): 429-443.

Kumar S, Calvo R, Avendano M, Sivaramakrishnan K, Berkman LF (2012) Social support, volunteering and health around the world: Cross-national evidence from 139 countries. Social Science \& Medicine 74(5): 696-706. 
Lee Y, Brudney JL (2012) Participation in formal and informal volunteering: Implications for volunteer recruitment. Nonprofit Management and Leadership 23(2): 159-180.

Li Y, Ferraro KF (2005) Volunteering and depression in later life: Social Benefit or selection processes?. Journal of Health and Social Behavior 46(1): 68-84.

Menchik PL, Weisbrod BA (1987) Volunteer Labor Supply. Journal of Public Economics 32(2): 159-83.

Nappo N (2013) Il perché del volontariato [Why Volunteering]. Bari: Cacucci Editore.

Petrou S, Kupek E (2008) Social capital and its relationship with measure of health status: evidence from the health survey from England 2003. Health Economics 17(1): 127-143.

Piliavin JA, Siegel E (2007) Health benefits of volunteering in the Wisconsin longitudinal study. Journal of Health and Social Behavior 48(4): 450-464.

Plagnol AC, Huppert FA (2010) Happy to help? Exploring the factors associated with variations in rates of volunteering across Europe. Social Indicators Research 97: 157-176.

Prouteau L, Wolff FC (2006) Does voluntary work pay off in the labour market? Journal of Socio Economic 35(6): 992-1013.

Schiff J (1990) Charitable giving and government policy. An economic analysis. New York: Greenwood Press.

Tang F (2009) Late-life volunteering and trajectories of physical health. Journal of Applied Gerontology 28(4): 524-533.

Uchino BN (2004) Social support and physical health: Understanding the health consequences of our relationships. New Haven, CT: Yale University Press.

Wilson J, Musick M (1997) Who cares? Toward an integrated theory of volunteer work. American Sociological Review 62(5): 694-713;

Wilson J (2000) Volunteering. Annual Review of Sociology 26: 215-240. 


\section{Appendix}

Table 5.Variable Definitions

\begin{tabular}{|c|c|}
\hline Variable & Description \\
\hline \multicolumn{2}{|l|}{ Dependent variable } \\
\hline $\begin{array}{l}\text { Self-perceived good } \\
\text { health }\end{array}$ & Individual assessment of health. Dummy, $1=$ good and very good; 0 otherwise \\
\hline \multicolumn{2}{|c|}{ Key independent variables } \\
\hline Formal Volunteering & $\begin{array}{l}\text { Dummy, } 1 \text { if the respondent, during the last twelve months, participated in the } \\
\text { unpaid work of charitable organizations, groups or clubs. It includes unpaid } \\
\text { charitable work for churches, religious groups and humanitarian organizations. } \\
\text { Attending meetings connected with these activities is included; } 0 \text { otherwise }\end{array}$ \\
\hline Informal Volunteering & $\begin{array}{l}\text { Dummy, } 1 \text { if the respondent, during the last twelve months, undertook (private) } \\
\text { voluntary activities to help someone, such as cooking for others; taking care of } \\
\text { people in hospitals/at home; taking people for a walk. It excludes any activity } \\
\text { that a respondent undertakes for his/her household, in his/her work or within } \\
\text { voluntary organizations; } 0 \text { otherwise }\end{array}$ \\
\hline \multicolumn{2}{|c|}{ Demographic and socio-economic characteristics } \\
\hline Female & Dummy, 1 if female; 0 otherwise. Reference group: male \\
\hline Married & Dummy, 1 if married; 0 otherwise; Reference group: single status \\
\hline Separated/divorced & Dummy, 1 if separated/divorced; 0 otherwise \\
\hline Widowed & Dummy, 1 if widowed; 0 otherwise \\
\hline Age $31-50$ & $\begin{array}{l}\text { Age of the respondent. Dummy, } 1 \text { if age between } 31 \text { and 50. Reference group: } \\
\text { age } \mathbf{1 6 - 3 0}\end{array}$ \\
\hline Age 51- 64 & Age of the respondent. Dummy, 1 if age between 51 and 64 \\
\hline Age $>65$ & Age of the respondent. Dummy, 1 if age above 65 \\
\hline Lower secondary edu & $\begin{array}{l}\text { Dummy, } 1 \text { if the respondent has attained lower secondary education; } 0 \\
\text { otherwise. Reference group: no education/primary education }\end{array}$ \\
\hline Secondary edu & Dummy, 1 if the respondent has attained secondary education; 0 otherwise \\
\hline Tertiary edu & Dummy, 1 if the respondent has attained tertiary education; 0 otherwise \\
\hline Household size & Number of household members \\
\hline EU birth & $\begin{array}{l}\text { Dummy, } 1 \text { if the respondent was born in a European Union country; } 0 \\
\text { otherwise. Reference group: country of residence }\end{array}$ \\
\hline OTH birth & Dummy, 1 if the respondent was born in any other country; 0 otherwise \\
\hline $\begin{array}{l}\text { Household income } \\
(\ln )\end{array}$ & Natural log of total disposal household income (HY020) \\
\hline $\begin{array}{l}\text { Unmet need for } \\
\text { medical examination }\end{array}$ & $\begin{array}{l}\text { Dummy 1, if there was at least one occasion when the person really needed } \\
\text { examination or treatment but did not; } 0 \text { otherwise }\end{array}$ \\
\hline Homeowner & Dummy, 1 if the respondent owns the house where he /she lives; 0 otherwise \\
\hline Employed part time & $\begin{array}{l}\text { Self-defined current economic status of the respondents; } 1=\text { employed part } \\
\text { time; Reference group: employed full time }\end{array}$ \\
\hline Unemployed & $\begin{array}{l}\text { Self-defined current economic status of the respondents; } 1=\text { unemployed; } 0 \\
\text { otherwise }\end{array}$ \\
\hline Student & $\begin{array}{l}\text { Self-defined current economic status of the respondents; } 1=\text { student; } 0 \\
\text { otherwise }\end{array}$ \\
\hline Retired & $\begin{array}{l}\text { Self-defined current economic status of the respondents; } 1=\text { retired; } 0 \\
\text { otherwise }\end{array}$ \\
\hline Disabled & $\begin{array}{l}\text { Self-defined current economic status of the respondents; } 1=\text { permanently } \\
\text { disabled; } 0 \text { otherwise }\end{array}$ \\
\hline Domestic tasks & $\begin{array}{l}\text { Self-defined current economic status of the respondents; } 1=\text { domestic tasks; } 0 \\
\text { otherwise }\end{array}$ \\
\hline Inactive & $\begin{array}{l}\text { Self-defined current economic status of the respondents; } 1=\text { other inactive } \\
\text { person; } 0 \text { otherwise }\end{array}$ \\
\hline \multicolumn{2}{|l|}{ Housing feature } \\
\hline Home warm & $\begin{array}{l}\text { Dummy, } 1 \text { if the respondent is able to pay to keep the home adequately warm; } 0 \\
\text { otherwise }\end{array}$ \\
\hline Home dark problem & $\begin{array}{l}\text { Dummy, } 1 \text { if the respondent feels the dwelling is too dark, not enough light; } 0 \\
\text { otherwise }\end{array}$ \\
\hline
\end{tabular}




\begin{tabular}{|c|c|}
\hline Variable & Description \\
\hline \multicolumn{2}{|l|}{ Neighborhood quality } \\
\hline Noise & $\begin{array}{l}\text { Dummy, } 1 \text { if the respondent feels noise from neighbors is a problem for the } \\
\text { household; } 0 \text { otherwise }\end{array}$ \\
\hline Pollution & $\begin{array}{l}\text { Dummy, } 1 \text { if the respondent feels pollution, grime or other environmental } \\
\text { problems are a problem for the household, } 0 \text { otherwise }\end{array}$ \\
\hline Crime & $\begin{array}{l}\text { Dummy, } 1 \text { if the respondent feels crime, violence or vandalism is a problem for } \\
\text { the household; } 0 \text { otherwise }\end{array}$ \\
\hline \multicolumn{2}{|l|}{ Size of municipality } \\
\hline $\begin{array}{l}\text { Densely populated } \\
\text { area }\end{array}$ & $\begin{array}{l}\text { Dummy, } 1 \text { if the respondent lives in local areas where the total population for } \\
\text { the set is at least } 50,000 \text { inhabitants. Reference Group: Thinly-populated area }\end{array}$ \\
\hline Intermediate area & $\begin{array}{l}\text { Dummy, } 1 \text { if the respondent lives in local areas, not belonging to a densely- } \\
\text { populated area, and either with a total population for the set of at least } 50,000 \\
\text { inhabitants or adjacent to a densely-populated area. }\end{array}$ \\
\hline \multicolumn{2}{|c|}{ Other social and cultural participation variables } \\
\hline $\begin{array}{l}\text { Political parties or } \\
\text { trade unions }\end{array}$ & $\begin{array}{l}\text { Dummy, } 1 \text { if the respondent, during the last twelve months, participated in } \\
\text { activities related to political groups, political association, political parties or } \\
\text { trade unions. Attending meetings connected with these activities is included; } 0 \\
\text { otherwise }\end{array}$ \\
\hline $\begin{array}{l}\text { Professional } \\
\text { participation }\end{array}$ & $\begin{array}{l}\text { Dummy, } 1 \text { if the respondent, during the last twelve months, participated in } \\
\text { activities related to a professional association. Attending meetings connected } \\
\text { with these activities is included; } 0 \text { otherwise }\end{array}$ \\
\hline $\begin{array}{l}\text { Religious } \\
\text { participation }\end{array}$ & $\begin{array}{l}\text { Dummy, } 1 \text { If the respondent, during the last twelve months, participated in } \\
\text { activities related to churches, religious communions or associations. Attending } \\
\text { holy masses or similar religious acts or helping during these services is also } \\
\text { included; } 0 \text { otherwise }\end{array}$ \\
\hline $\begin{array}{l}\text { Recreational } \\
\text { participation }\end{array}$ & $\begin{array}{l}\text { Dummy, } 1 \text { if the respondent, during the last twelve months, participated in } \\
\text { recreational/leisure activities arranged by a club, association or similar. } \\
\text { Attending meetings connected with these activities is included; } 0 \text { otherwise }\end{array}$ \\
\hline $\begin{array}{l}\text { Other organizations } \\
\text { paarticipation }\end{array}$ & $\begin{array}{l}\text { Dummy, } 1 \text { if the respondent, during the last twelve months, participated in the } \\
\text { activities of environmental organizations, civil rights groups, neighbourhood } \\
\text { associations, peace groups etc. Attending meetings connected with these } \\
\text { activities is included; } 0 \text { otherwise }\end{array}$ \\
\hline Meetings with friends & $\begin{array}{l}\text { Dummy 1, if the respondent gets together with friends every day or several } \\
\text { times a week during a usual year; } 0 \text { otherwise }\end{array}$ \\
\hline Cinema & Dummy. 1 if the respondent goes to the cinema 1-3 times a year; 0 otherwise \\
\hline Live performance & $\begin{array}{l}\text { Dummy. } 1 \text { if the respondent goes to any live performance (plays, concerts, } \\
\text { operas, ballet and dance performances) 1-3 times a year; } 0 \text { otherwise }\end{array}$ \\
\hline Cultural site & $\begin{array}{l}\text { Dummy. } 1 \text { if the respondent visits historical monuments, museum, art galleries } \\
\text { or archeological sites } 1-3 \text { times a year; } 0 \text { otherwise }\end{array}$ \\
\hline Sport events & $\begin{array}{l}\text { Dummy. } 1 \text { if the respondent attends live sport events 1-3 times a year; } 0 \\
\text { otherwise }\end{array}$ \\
\hline
\end{tabular}


